\title{
Diurnal cycle of rainfall over the Brazilian Amazon
}

\author{
Carlos F. Angelis*, Glenn R. McGregor, Chris Kidd \\ University of Birmingham, School of Geography, Earth and Environmental Sciences, Birmingham B15 2TT, UK
}

\begin{abstract}
The rainfall characteristics over the Brazilian Amazon were analysed using $3 \mathrm{yr}$ of $3 \mathrm{~h}$ data from 24 rain gauges. During this period, areas in the eastern sector experienced up to $22 \%$ of rainy hours, while those in the southern sector recorded up to $7 \%$. In the northern Amazon, rain tends to occur during the night, while in southern, central and central-western Amazon it occurs mainly in the afternoon. In contrast, over the eastern Amazon, rain occurs late at night and early in the morning. Harmonic analysis revealed an increase in the phase of the first harmonic phase from eastern towards central Amazon, suggesting that the rain propagates in that direction. The amplitude of the first and second harmonics revealed the existence of a relatively dry area inland about $500 \mathrm{~km}$ from the Atlantic coast. This area seems to be the limit for the inland penetration of systems originating at the coast. The phase of the first harmonic revealed small differences between the diurnal cycles of rainfall during the wet and dry seasons, suggesting that there is no difference between low-level circulations in either season.
\end{abstract}

KEY WORDS: Amazon $\cdot$ Diurnal cycle $\cdot$ Rainfall $\cdot$ Precipitation $\cdot$ Rain gauge

Resale or republication not permitted without written consent of the publisher

\section{INTRODUCTION}

The large spatial and temporal variability of the precipitation regime over the Amazon can be related to dynamic aspects of the regional atmospheric circulation. During the austral summer (December-February) and autumn (March-May), rainfall over the Amazon Basin reaches its maximum, with the largest annual amounts increasing from the central and southern Amazon towards the northern Amazon. During the austral winter (June-August) and spring (September-November), rainfall is at its minimum over most of the area. The region exhibits 3 main centres of high precipitation located in its northwestern, central and eastern parts, which experience about 3000, 2500 and $2800 \mathrm{~mm} \mathrm{yr}^{-1}$, respectively (Figueroa \& Nobre 1990, Rao \& Hada 1990, Souza et al. 2000). Rain-gauge measurements show that the annual amount of precipitation over the Brazilian Amazon ranges from 1267 to $3549 \mathrm{~mm}$ (De Paiva \& Clarke 1995). Changes in the precipitation regime over this area have been related to El Niño, La Niña and variations in the sea-surface temperature in the Atlantic Ocean (Marengo 1992, Souza et al. 2000). El Niño and an Atlantic positive dipole (negative dipole) occurring together contribute to decreasing (increasing) rainfall over the region. In addition, precipitation over some parts of the Amazon can be influenced by the North Atlantic High and the Tropical Atlantic sea-surface temperature (Costa \& Foley 1999). The precipitation regime over the Amazon is mainly modulated by the Inter-Tropical Convergence Zone (ITCZ), the South Atlantic Convergence Zone (SACZ) and the Bolivian High (Kodama 1992, Nobre \& Shukla 1996, Kayano et al. 1997).

Although the annual and monthly behaviour of precipitation over the Amazon has received much coverage in the literature, little attention has been given to the diurnal cycle of rainfall. Dai (2001) however, has found that non-showery precipitation tends to occur at about 06:00 h Local Solar Time (LST) over most land areas, and between 00:00 and 04:00 LST over many oceanic areas. Over the North Pacific, North Atlantic and many other oceanic areas near the continents, showery precipitation occurs at about 06:00 h LST. Over the tropical and southern oceans, precipitation maxima tend to occur at around 04:00 h LST. Over most land areas in the Tropics, showery precipitation and thunderstorms occur more often late in the after- 


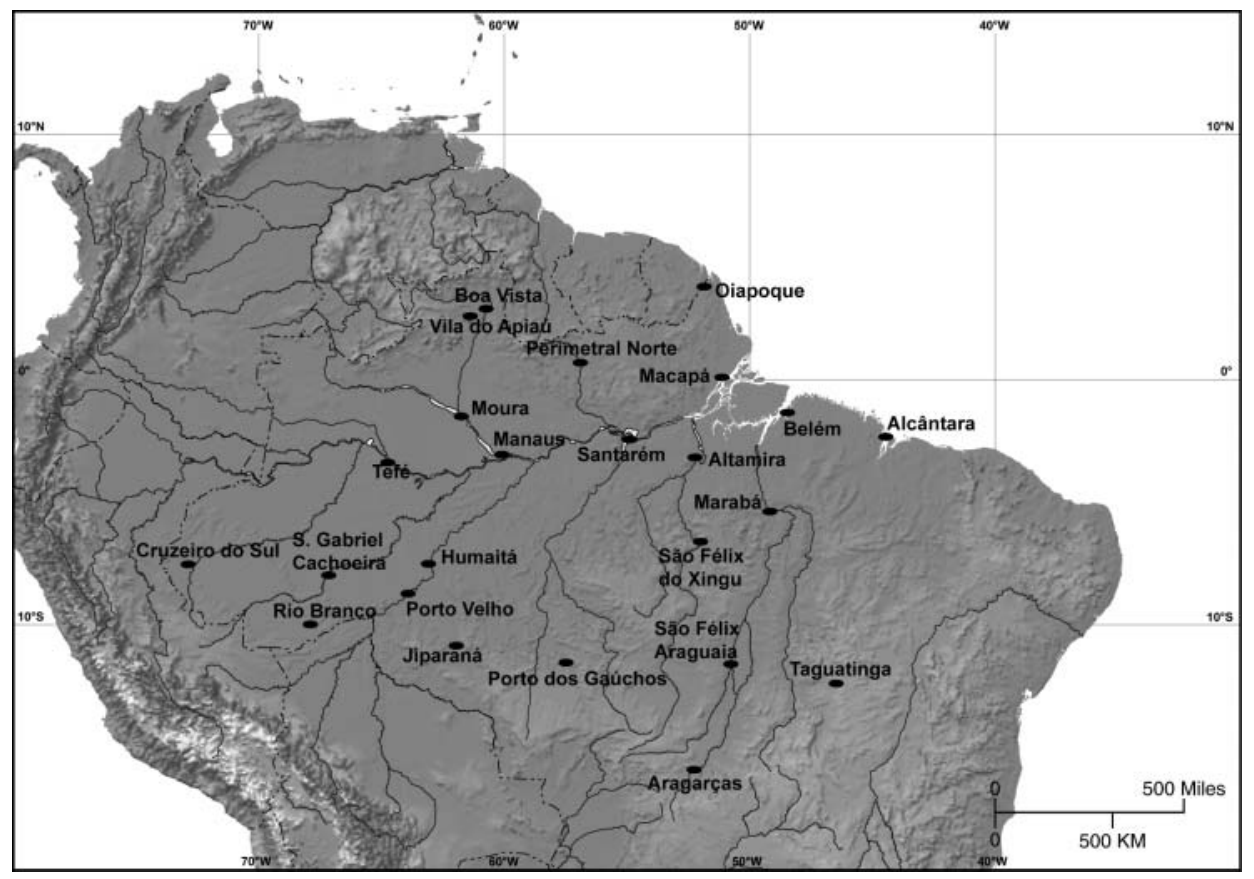

Fig. 1. Study area and location of the rain gauges

noon, from about 15:00 to 19:00 h LST (Dai 2001). The phase of convective activity over land in the South and Central Americas, South and Central Africa, India and Borneo is generally from late afternoon to evening (Houze et al. 1981, Hendon \& Woodberry 1993, Yang \& Slingo 2001). Specifically over the eastern coast of the Amazon, it has been found that peaks of rainfall tend to occur at 05:00 h LST in Marajó Island and at 17:00 h LST in Belém (Kousky 1980). In the central Amazon, near the convergence between the Amazonas and Negro rivers and over the Reserva Florestal Ducke, located at $25 \mathrm{~km}$ from Manaus, peaks of precipitation occur at 12:00 and 15:00 h LST, respectively (Lloyd 1990, Cutrim et al. 2000).

Despite the low rain-gauge density over the Amazon Basin, the pluviometers in that area are sufficient to allow evaluation of some rainfall characteristics and also to be very useful as ground truth for satellite applications. The main purpose of the present study is to analyse $3 \mathrm{yr}$ of previously unavailable rain-gauge data over the Brazilian Amazon so as to increase knowledge of the diurnal variations of rainfall over this area.

\section{DATA AND ANALYSIS METHOD}

The nature of the diurnal rainfall cycle was established using harmonic analysis, which yields information about the amplitude and phase (timing) of the peak in a time series. The methodology followed is that outlined by Wilks (1995). Accordingly, rainfall is modelled at time $t$ in a series $y$ by the harmonic function:

$$
y_{t}=y+C_{k} \cos \left(2 \pi t / n-\phi_{k}\right)
$$

where $y$ is the mean of the series, $n$ is the period, $C$ is the amplitude, $\phi$ is the phase and $k$ is the harmonic number. The amplitude $C$ is estimated by:

where

$$
C_{1}=\left[A_{1}^{2}+B_{1}^{2}\right]^{1 / 2}
$$

$$
\begin{aligned}
A_{1} & =2 / n \times \Sigma y_{t} \cos (2 \pi t / n) \\
B_{1} & =2 / n \times \Sigma y_{t} \sin (2 \pi t / n)
\end{aligned}
$$

The phase can then be derived using:

$$
\begin{array}{ll}
\phi_{1}=\tan ^{-1}\left(B_{1} / A_{1}\right) \pm \pi & \text { if } A_{1}<0 \\
\phi_{1}=\tan ^{-1}\left(\mathrm{~B}_{1} / \mathrm{A}_{1}\right) & \text { if } A_{1}>0 \\
\phi_{1}=\pi / 2 & \text { if } A=0
\end{array}
$$

For this analysis $n=8$ : eight 3 h observations of rainfall over a $24 \mathrm{~h}$ cycle starting at $t=00: 00 \mathrm{~h}$.

Rainfall observations from 24 meteorological stations spread over the Brazilian Amazon covering the period from 1 January 1998 to 31 December 2000 were used in the analysis. The data were supplied by Centro de Previsão de Tempo e Estudos Climáticos-CPTECINPE (Centre for Weather Forecast and Climate Studies), Agência Nacional de Energia Elétrica-ANEEL (Brazilian National Agency for Electric Energy), and Instituto de Aeronáutica e Espaço-Divisão de Ciên- 
cias Atmosféricas-IAE-DCA (Brazilian Institute of Aeronautics and Space-Division of Atmospheric Sciences). ANEEL and CPTEC-INPE supplied data on an hourly and $3 \mathrm{~h}$ basis, respectively (pluviometer resolution equal to $1 \mathrm{~mm}$ ). IAE-DCA supplied data on an hourly basis (pluviometer resolution equal to $0.2 \mathrm{~mm}$ ). Fig. 1 shows the rain-gauge locations in the study area.

Due to format differences, all data sets were reformatted to be consistent with the CPTEC-INPE $3 \mathrm{~h}$ data set. The time reference used was Greenwich Mean Time (GMT). Valid data were defined as the mean rainfall which occurred each $3 \mathrm{~h}$ and a rain event was defined as any valid data greater than $0 \mathrm{~mm} \mathrm{~h}^{-1}$. A missing-data analysis was performed in order to evaluate the reliability of the data, and descriptive statistics were computed using the entire data set. As described above, harmonic analysis was applied to the entire data set in an attempt to model the form of the diurnal cycle of rainfall over the study area. The original data set was also stratified into dry (December-May)- and wet (June-November)-season data sets in order to establish whether seasonal differences in diurnal rainfall characteristics exist.

\section{RESULTS AND DISCUSSION}

\subsection{Missing-data analysis}

The results of the missing-data analysis are shown in Table 1. Total and hourly percentages of missing data for each rain gauge are shown; these percentages were assessed using the ratio between the total of valid data values recorded by a rain gauge and the total of possible valid values over the study period (8768 values). All rain gauges were included in the study because, despite the high values of total missing data for some rain gauges, their hourly distribution was low.

\subsection{Diurnal frequency of rain events}

Fig. 2 shows the frequency of rain events per hour for each rain gauge. At northern Amazon sites near the coast, most of the rain events occur in the morning, while sites located in the interior have a maximum of rain events at night. In the eastern Amazon, Alcântara, Santarém and Marabá exhibit peaks of rain events at night, while in Belém, Altamira and São Félix do Xingu

Table 1. Percentages (\%) of total and hourly (GMT) missing data at each station

\begin{tabular}{|c|c|c|c|c|c|c|c|c|c|c|}
\hline \multicolumn{2}{|c|}{ Stn } & $00: 00 \mathrm{~h}$ & 03:00 h & 06:00 h & 09:00 h & $12: 00 \mathrm{~h}$ & $15: 00 \mathrm{~h}$ & $18: 00 \mathrm{~h}$ & $21: 00 \mathrm{~h}$ & Total \\
\hline \multicolumn{11}{|c|}{ Northern } \\
\hline 1 & Boa Vista & 0.00 & 0.00 & 0.00 & 0.00 & 0.00 & 0.00 & 0.00 & 0.00 & 00.00 \\
\hline 2 & V. Apiaú & 6.15 & 6.15 & 6.14 & 6.14 & 6.14 & 6.14 & 6.14 & 6.08 & 49.05 \\
\hline 3 & P. Norte & 2.90 & 2.73 & 3.10 & 2.95 & 2.84 & 2.74 & 3.20 & 2.99 & 23.45 \\
\hline 4 & Macapá & 0.00 & 0.00 & 0.00 & 0.00 & 0.00 & 0.00 & 0.00 & 0.00 & 00.00 \\
\hline 5 & Oiapoque & 3.19 & 3.20 & 3.32 & 3.33 & 3.35 & 3.40 & 3.35 & 3.22 & 26.37 \\
\hline \multicolumn{11}{|c|}{ Eastern } \\
\hline 6 & Belém & 0.00 & 0.00 & 0.00 & 0.00 & 0.00 & 0.00 & 0.00 & 0.00 & 00.00 \\
\hline 7 & Alcântara & 1.16 & 1.16 & 1.16 & 1.16 & 1.16 & 1.16 & 1.15 & 1.15 & 09.28 \\
\hline 8 & Santarém & 0.00 & 0.00 & 0.00 & 0.00 & 0.00 & 0.00 & 0.00 & 0.00 & 00.00 \\
\hline 9 & Altamira & 2.55 & 2.55 & 2.55 & 2.55 & 2.55 & 2.55 & 2.55 & 2.58 & 20.45 \\
\hline 10 & Marabá & 2.04 & 2.01 & 2.02 & 2.02 & 1.98 & 1.96 & 1.98 & 2.02 & 16.04 \\
\hline 11 & S. F. Xingu & 0.35 & 0.35 & 0.35 & 0.35 & 0.35 & 0.35 & 0.35 & 0.36 & 02.84 \\
\hline \multicolumn{11}{|c|}{ Central } \\
\hline 12 & Moura & 3.57 & 3.30 & 3.59 & 3.73 & 3.55 & 3.76 & 4.24 & 3.74 & 29.49 \\
\hline 13 & Tefé & 1.72 & 1.73 & 1.72 & 1.52 & 1.60 & 1.89 & 2.14 & 1.53 & 13.85 \\
\hline 14 & Manaus & 0.00 & 0.00 & 0.00 & 0.00 & 0.00 & 0.00 & 0.00 & 0.00 & 00.00 \\
\hline \multicolumn{11}{|c|}{ Central-Western } \\
\hline 15 & Humaitá & 4.30 & 4.28 & 4.31 & 4.36 & 4.36 & 4.31 & 4.32 & 4.39 & 34.63 \\
\hline 16 & P. Velho & 0.00 & 0.00 & 0.00 & 0.00 & 0.00 & 0.00 & 0.00 & 0.00 & 00.00 \\
\hline 17 & S. G. Cachoeira & 5.25 & 5.16 & 4.98 & 4.96 & 4.89 & 5.09 & 5.08 & 5.25 & 40.65 \\
\hline 18 & C. Sul & 4.31 & 4.28 & 4.27 & 4.35 & 4.39 & 4.38 & 4.41 & 4.41 & 34.80 \\
\hline 19 & Rio Branco & 0.00 & 0.00 & 0.00 & 0.00 & 0.00 & 0.00 & 0.00 & 0.00 & 00.00 \\
\hline 20 & Jiparaná & 2.91 & 2.91 & 2.91 & 2.92 & 2.92 & 2.92 & 2.92 & 2.92 & 23.31 \\
\hline \multicolumn{11}{|c|}{ Southern } \\
\hline 21 & P. Gaúchos & 3.65 & 3.65 & 3.66 & 3.71 & 3.72 & 3.71 & 3.71 & 3.71 & 29.51 \\
\hline 22 & S. F. Araguaia & 0.00 & 0.00 & 0.00 & 0.00 & 0.00 & 0.00 & 0.00 & 0.00 & 00.00 \\
\hline 23 & Taguatinga & 0.00 & 0.00 & 0.00 & 0.00 & 0.00 & 0.00 & 0.00 & 0.00 & 00.00 \\
\hline 24 & Aragarças & 1.65 & 1.68 & 1.65 & 1.67 & 1.68 & 1.67 & 1.68 & 1.70 & 13.37 \\
\hline
\end{tabular}



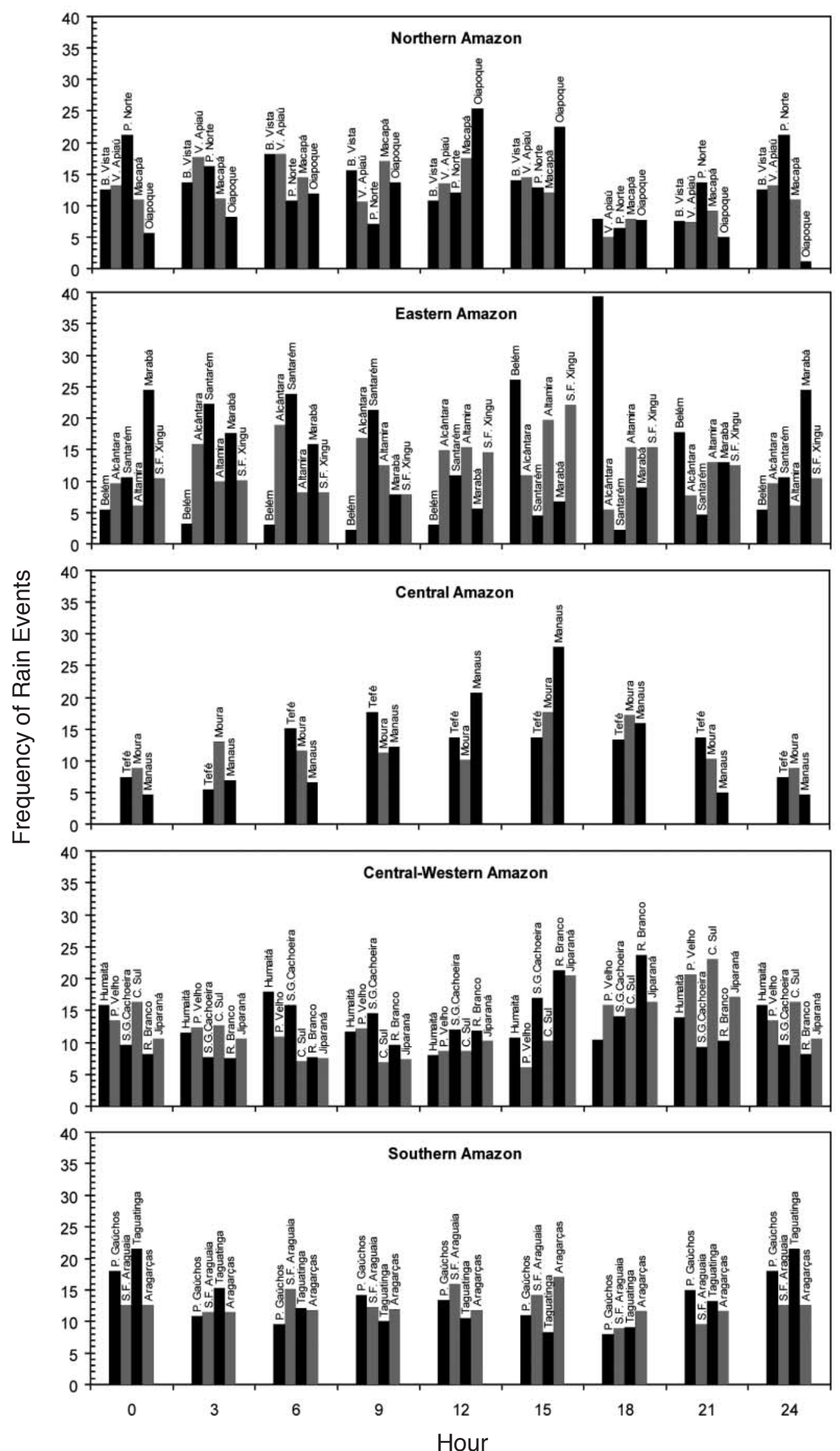

Fig. 2. Distribution of the frequency of rain events (\%) per hour (GMT) 
peaks occur in the afternoon. In the central Amazon, most of the rain events occur during the day; however, in Tefé the highest values occur in the morning, while in Moura and Manaus they occur in the afternoon. In the central-western Amazon, rain events tend to occur during the day, mainly in the afternoon, except for Humaitá, where they tend to occur at night. In the southern Amazon, the highest percentages of rain events occur in the evening.

\subsection{Rain-gauge descriptive statistics}

The main statistics of the rain-gauge data set are shown in Tables 2 \& 3 . In the northern Amazon, Oiapoque records both the highest mean rain rate and the highest proportion of rainy hours of all stations. Boa Vista exhibits the lowest mean rain rate for all hours and the highest rain rate for rainy hours. Although it seems to be the driest rain gauge in the northern Amazon, it has the highest intensity of rain. The maximum rainfall registered for Boa Vista in a period of $3 \mathrm{~h}$ was

Table 2. Rainfall statistics for all hours. Hours of data: total of valid data registered by a given rain gauge

\begin{tabular}{|c|c|c|c|c|}
\hline \multicolumn{2}{|c|}{ Stn } & $\begin{array}{l}\text { Hours } \\
\text { of data }\end{array}$ & $\begin{array}{l}\text { Mean rain rate } \\
\quad\left(\mathrm{mm} \mathrm{h}^{-1}\right)\end{array}$ & $\begin{array}{c}\mathrm{SD} \\
\left(\mathrm{mm} \mathrm{h}^{-1}\right.\end{array}$ \\
\hline \multicolumn{5}{|c|}{ Northern } \\
\hline 1 & Boa Vista & 8768 & 0.243 & 1.351 \\
\hline 2 & V. Apiaú & 4467 & 0.266 & 0.938 \\
\hline 3 & P. Norte & 3368 & 0.257 & 1.115 \\
\hline 4 & Macapá & 8768 & 0.268 & 1.006 \\
\hline 5 & Oiapoque & 6456 & 0.345 & 0.649 \\
\hline \multicolumn{5}{|c|}{ Eastern } \\
\hline 6 & Belém & 8768 & 0.385 & 0.985 \\
\hline 7 & Alcântara & 7954 & 0.196 & 1.109 \\
\hline 8 & Santarém & 8768 & 0.250 & 0.948 \\
\hline 9 & Altamira & 6974 & 0.223 & 1.313 \\
\hline 10 & Marabá & 7362 & 0.232 & 1.264 \\
\hline 11 & S. F. Xingu & 8519 & 0.120 & 0.799 \\
\hline \multicolumn{5}{|c|}{ Central } \\
\hline 12 & Moura & 6198 & 0.237 & 1.103 \\
\hline 13 & Tefé & 3489 & 0.246 & 1.009 \\
\hline 14 & Manaus & 8768 & 0.264 & 0.581 \\
\hline \multicolumn{5}{|c|}{ Central-Western } \\
\hline 15 & Humaitá & 5732 & 0.256 & 1.679 \\
\hline 16 & P. Velho & 8768 & 0.276 & 1.387 \\
\hline 17 & S. G. Cachoeira & 5204 & 0.368 & 1.244 \\
\hline 18 & C. Sul & 5717 & 0.225 & 1.290 \\
\hline 19 & Rio Branco & 8768 & 0.193 & 1.015 \\
\hline 20 & Jiparaná & 6723 & 0.191 & 1.554 \\
\hline \multicolumn{5}{|c|}{ Southern } \\
\hline 21 & P. Gaúchos & 6181 & 0.187 & 0.924 \\
\hline 22 & S. F. Araguaia & 8768 & 0.162 & 0.870 \\
\hline 23 & Taguatinga & 8768 & 0.154 & 0.870 \\
\hline 24 & Aragarças & 7596 & 0.187 & 1.295 \\
\hline
\end{tabular}

Table 3. Statistics for rainy hours. Rainy hours: total of valid data and the total of rain events registered by a given rain gauge. Proportion of rainy hours: ratio between 'rainy hours' and 'hours of data' (Table 2) times 100

\begin{tabular}{|c|c|c|c|c|c|}
\hline Stn & & $\begin{array}{l}\text { Rainy } \\
\text { hours }\end{array}$ & $\begin{array}{c}\text { Proportion } \\
\text { of rainy } \\
\text { hours (\%) }\end{array}$ & $\begin{array}{l}\text { Mean rain } \\
\text { rate } \\
\left(\mathrm{mm} \mathrm{h}^{-1}\right)\end{array}$ & $\frac{\mathrm{SD}}{\left(\mathrm{mm} \mathrm{h}^{-1}\right)}$ \\
\hline \multicolumn{6}{|c|}{ Northern } \\
\hline 1 & Boa Vista & 1120 & 12.77 & 2.661 & 3.584 \\
\hline 2 & V. Apiaú & 704 & 15.76 & 2.248 & 2.699 \\
\hline 3 & P. Norte & 459 & 13.63 & 1.816 & 2.515 \\
\hline 4 & Macapá & 1511 & 17.23 & 2.596 & 3.211 \\
\hline & Oiapoque & 1214 & 18.80 & 1.828 & 2.450 \\
\hline \multicolumn{6}{|c|}{ Eastern } \\
\hline 6 & Belém & 1901 & 21.68 & 2.642 & 3.049 \\
\hline 7 & Alcântara & 1042 & 13.10 & 2.179 & 2.771 \\
\hline 8 & Santarém & 1110 & 12.66 & 2.981 & 4.230 \\
\hline 9 & Altamira & 808 & 11.59 & 1.918 & 3.041 \\
\hline 10 & Marabá & 669 & 9.09 & 2.555 & 3.697 \\
\hline 11 & S. F. Xingu & 704 & 8.26 & 1.434 & 1.925 \\
\hline \multicolumn{6}{|c|}{ Central } \\
\hline 12 & Moura & 723 & 11.69 & 2.020 & 2.770 \\
\hline 13 & Tefé & 364 & 10.43 & 2.190 & 3.471 \\
\hline 14 & Manaus & 1439 & 16.41 & 2.580 & 3.077 \\
\hline \multicolumn{6}{|c|}{ Central-Western } \\
\hline & Humaitá & 586 & 10.22 & 2.508 & 4.031 \\
\hline 16 & P. Velho & 1320 & 15.05 & 3.054 & 3.775 \\
\hline 17 & S. G. Cachoeira & a 704 & 13.53 & 2.048 & 3.084 \\
\hline 18 & C. Sul & 580 & 10.15 & 2.213 & 3.149 \\
\hline 19 & Rio Branco & 1014 & 11.56 & 2.628 & 3.167 \\
\hline 20 & Jiparaná & 638 & 9.49 & 2.010 & 2.965 \\
\hline \multicolumn{6}{|c|}{ Southern } \\
\hline 21 & P. Gaúchos & 571 & 9.24 & 2.025 & 2.901 \\
\hline 22 & S. F. Araguaia & 625 & 7.13 & 2.269 & 3.059 \\
\hline 23 & Taguatinga & 659 & 7.52 & 1.936 & 2.660 \\
\hline 24 & Aragarças & 545 & 7.17 & 2.602 & 4.531 \\
\hline
\end{tabular}

$107.7 \mathrm{~mm}$, while the maximum for Oiapoque was $74 \mathrm{~mm}$. From the eastern towards the central Amazon, the mean rain rate for all hours and the proportion of rainy hours decreases, reaching the lowest values in São Félix do Xingu and Marabá, and increases again, reaching maximum values in Manaus and Porto Velho. The high mean rain rate exhibited by São Gabriel da Cachoeira, in the central-western Amazon, may be overestimated due to the lack of data during the dry season of 1999. All sites in the southern Amazon have low mean rain rates compared with other parts of this region. This might be due to the pronounced dry season over this area (shown in the following sections).

\subsection{Seasonality of the rainfall}

Fig. 3 shows the mean rain rate as a function of time (diurnal cycle) for each rain gauge in each season. Clear dry and wet periods are evident at each site. 

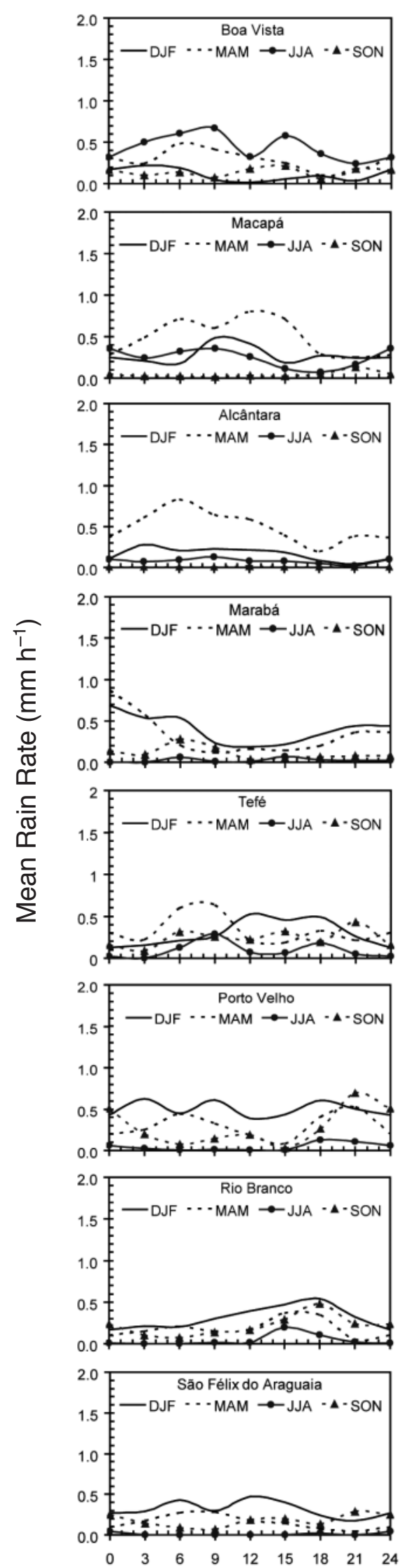
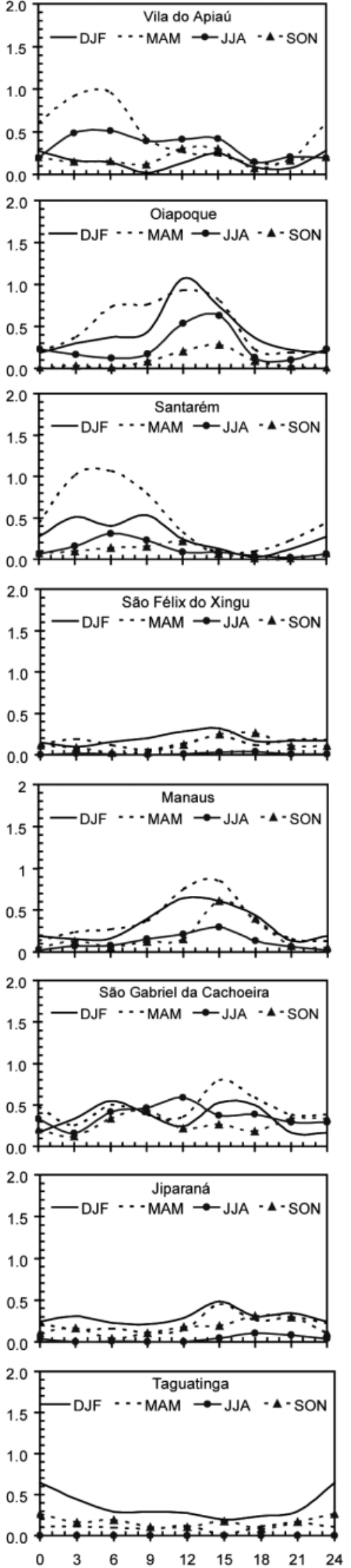

Hour
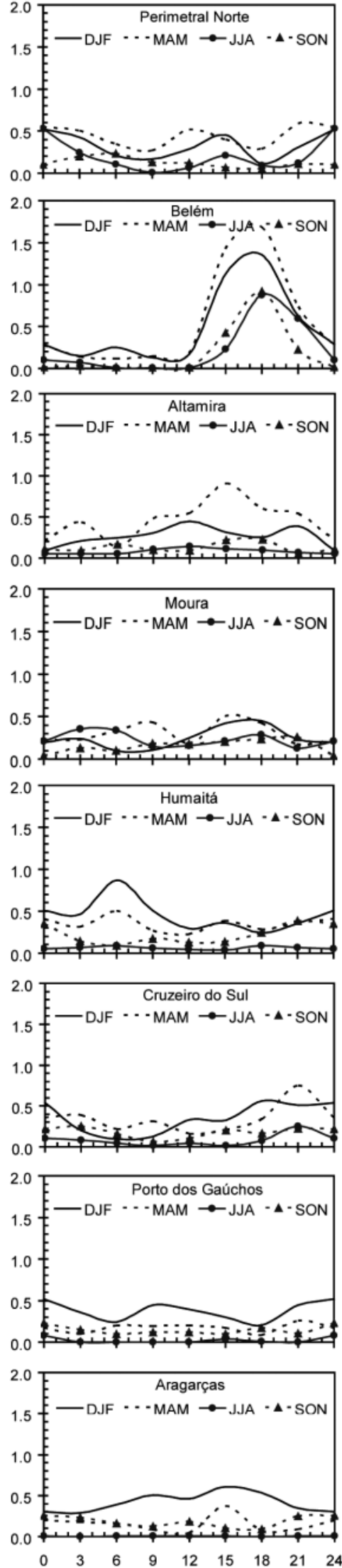

Fig. 3. Mean rain rate $\left(\mathrm{mm} \mathrm{h}^{-1}\right)$ per hour $(\mathrm{GMT})$ in each season. DJF: December-February; MAM: March-May; JJA: June-August; SON: September-November 
South of the Equator, rain gauges show higher values of mean rain rate in December-February (DJF) and March-May (MAM). In the central-western and southern Amazon, the wet season reaches its maximum in DJF, while in the eastern and central Amazon, it happens in MAM. At all sites, the dry season is more evident in June-August (JJA), except for Santarém, Belém and Alcantâra, where it occurs in September-November (SON).

North of the Equator, changes in the seasonality of the rain occur gradually northwards. In Macapá and Oiapoque, the wet (dry) season occurs from December to May (June to November) and reaches its maximum in MAM (SON). Perimetral Norte presents the same pattern; however, the dry season occurs in JJA. In Boa Vista and Vila do Apiaú, the wet (dry) season occurs from March to August (September to February) and reaches its maximum in JJA (DJF).

The mean rain rate for seasonal diurnal cycles seems to decrease from northern and eastern regions towards the southern Amazon; however, the time of maximum precipitation during different seasons seems to be similar at almost all the sites. Fig. 3 shows that the more southerly the station, the lower the amplitude of the mean rain rate. This is caused by long periods of no or very few rain events occurring in the southern Amazon, where, for example, only 9 rain events from a possible total of 736 observation points were registered at Aragarças during the period from 1 June to 31 August 2000.

\subsection{Harmonic analysis and annual diurnal cycle of rainfall}

Fig. 4 shows the sum of the first 2 harmonics plus the mean rain rate (Table 2), the annual diurnal cycle of rainfall assessed from the original data and the Pearson correlation between the two. Except for Aragarças, all rain gauges possess significant (at the level of 0.05) correlations.

Harmonic dials that portray the amplitude and phase of the first and second harmonics are shown in Figs. 5 \& 6, respectively. Belém shows the highest amplitude for the first and second harmonics and their phases point to 18:09 $\mathrm{h}$ GMT and 10:59/22:59 $\mathrm{h}$ GMT, respectively. From this area towards the central Amazon, the amplitude of both harmonics decreases up to Altamira, Marabá and São Félix do Xingu, and it increases again towards the central and western Amazon. This trend has been noted previously by others (Kousky 1980, Greco et al. 1990, Garstang et al. 1994) such that the convective activity produced at the Atlantic coast by sea and land breezes propagates inland towards the central Amazon, as squall lines which remain active for up to $48 \mathrm{~h}$. These instability lines are mesoscale to synoptic systems of generally linear orientation and travel at an average speed of 50 to $60 \mathrm{~km} \mathrm{~h}^{-1}$. A second convergence zone, ranging in size from $10^{3}$ to $10^{5} \mathrm{~km}^{2}$, originates in the central Amazon and moves westwards at speeds of 10 to $40 \mathrm{~km} \mathrm{~h}^{-1}$. The hours of daily maximum showed by the first harmonic seem to be in agreement with Greco et al. (1990) and Garstang et al. (1994). It is possible that the movement of both systems modulates the hour of maximum rainfall occurrence along their path and is responsible for the shift of the phase over the eastern and central Amazon.

The phases observed in this study are different from those presented by Lin et al. (2000), who used radar and passive microwave data from the Tropical Rainfall Measurement Mission (TRMM) satellite. The passive microwave data showed evening maxima over the central and southern Amazon and late-night maxima over the northern Amazon. Radar data indicated evening maxima over the southern portion of the Amazon. The differences between satellite and surface data possibly result from the low number of samples acquired by the satellite.

It is not clear whether there is an increase in phase from the central towards the western Amazon, due to the lack of stations between these areas. Instead, considering the trend of phase from the west towards the centre of the Amazon, one can see that the phase values seem to increase in that direction. If this is true, intriguing questions are raised, such as: (1) Could the convergence of katabatic flows originating over the eastern slopes of the Andes Cordillera with warm and moist air masses in the Andes foothills induce a convergence zone in that area? (2) Is it possible that systems originating in such a convergence zone could propagate towards the central Amazon? Unfortunately, the rain-gauge network is not dense enough to answer such questions. Although remote sensing might be used to shed light on the nature of the suggested mesoscale interactions, infrared imagery does not produce reliable information about the precipitation near the surface. Furthermore, passive microwave data do not have the requisite temporal resolution. An intermediary approach could be the use of data from the TRMM satellite, which carries the first orbital radar and passive microwave radiometer (Simpson et al. 1988, 1996, Kummerow et al. 1998, NASDA 2001, de Angelis et al. 2004).

\subsection{Harmonic analysis and seasonal diurnal cycle of rainfall}

A comparison of the amplitude and phase characteristics of the summer (December-May) and winter 

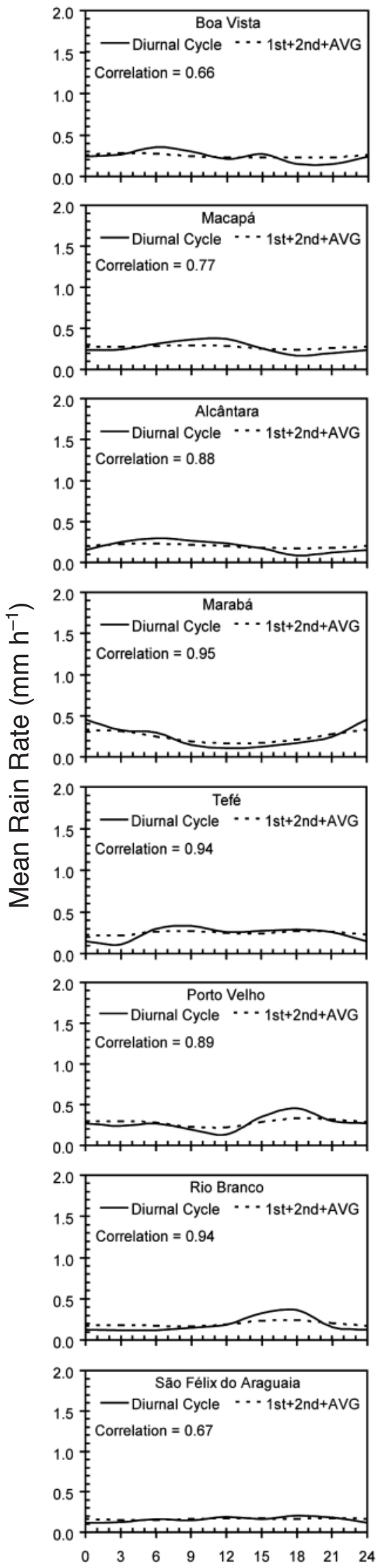
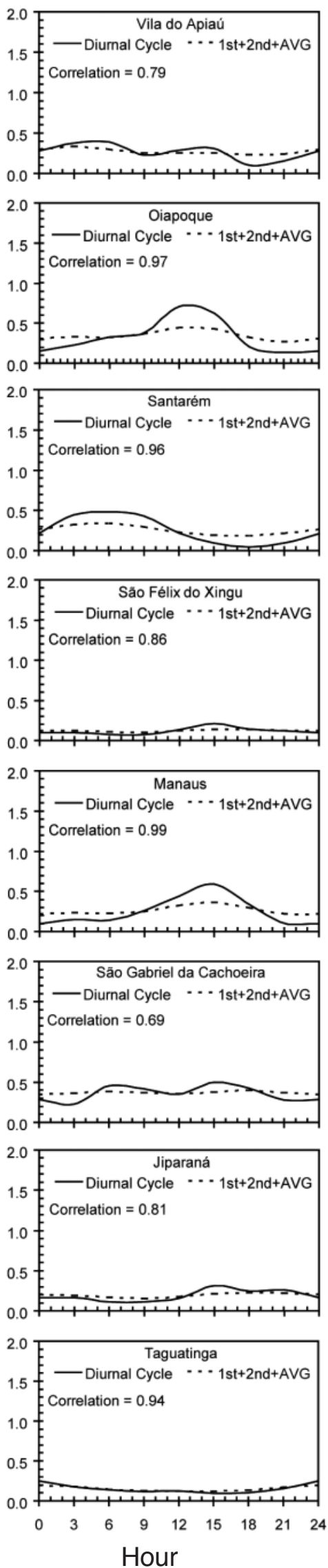
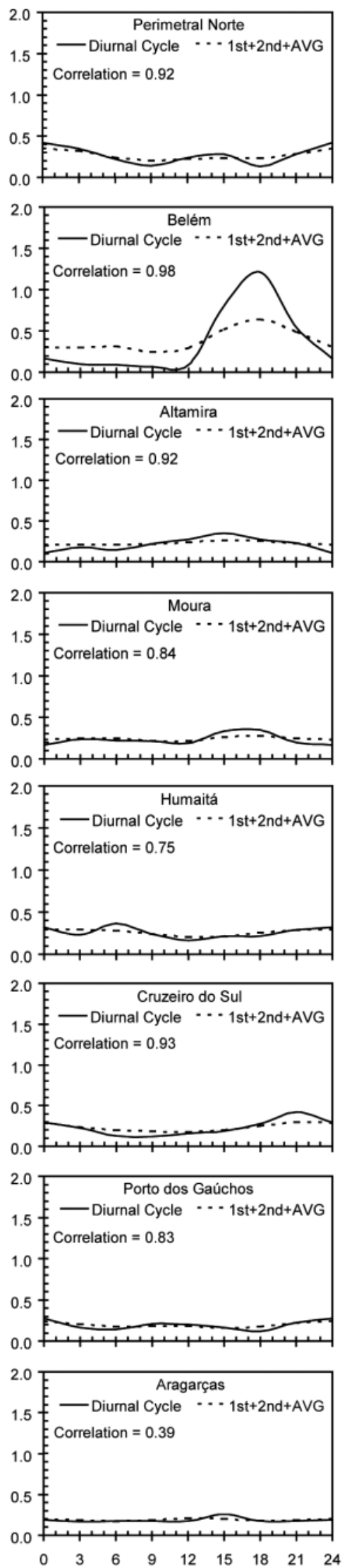

Fig. 4. Mean rain rate $\left(\mathrm{mm} \mathrm{h}^{-1}\right)$ per hour (GMT) for all seasons. Solid lines: annual diurnal cycle; dashed lines: sum of harmonics plus mean rain rate (Table 2 ) 


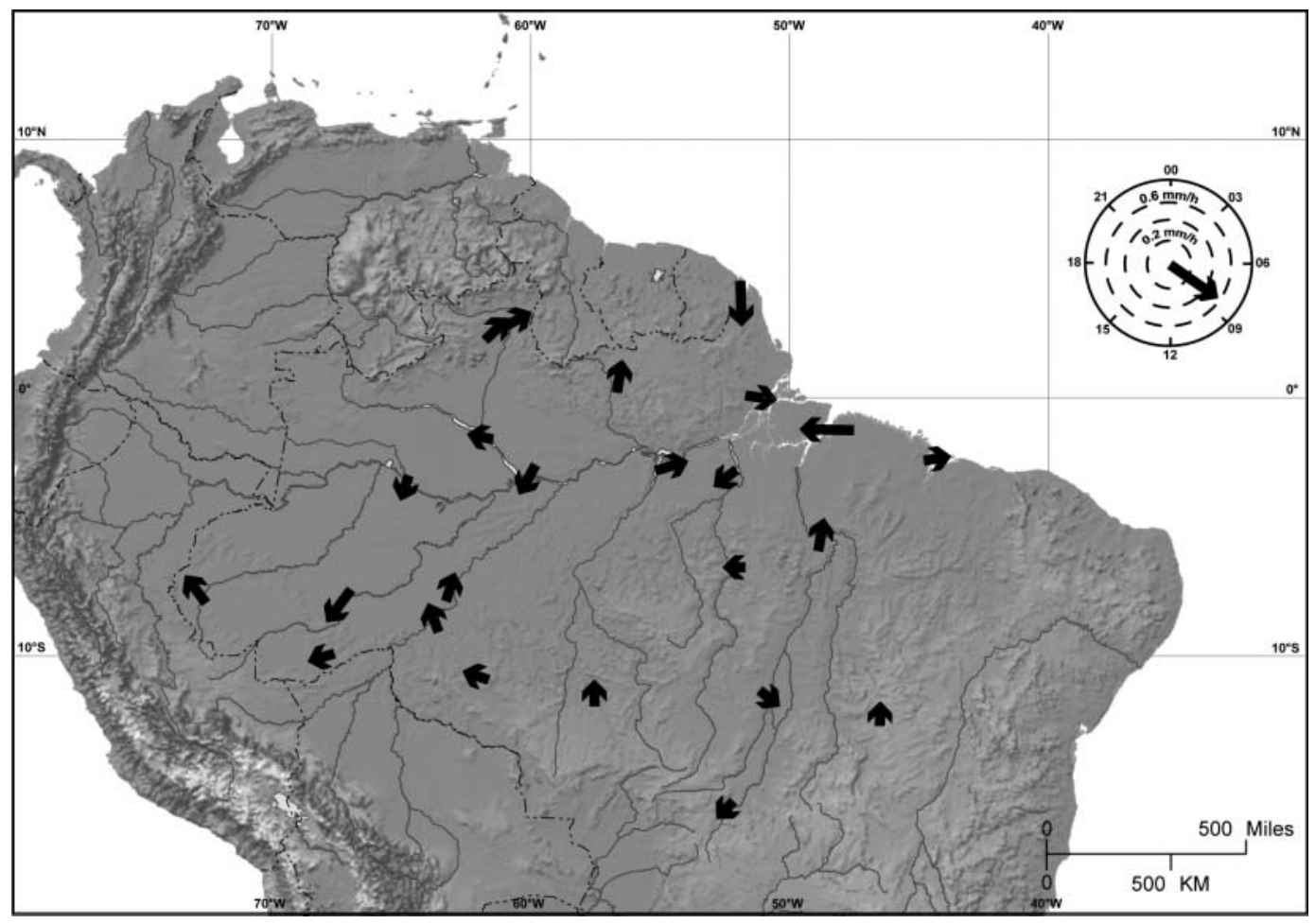

Fig. 5. Amplitude and phase of the first harmonic. The size of the arrow indicates the amplitude plus the mean rain rate for all hours. The arrow points to the hour (GMT) when the harmonic reaches its maximum

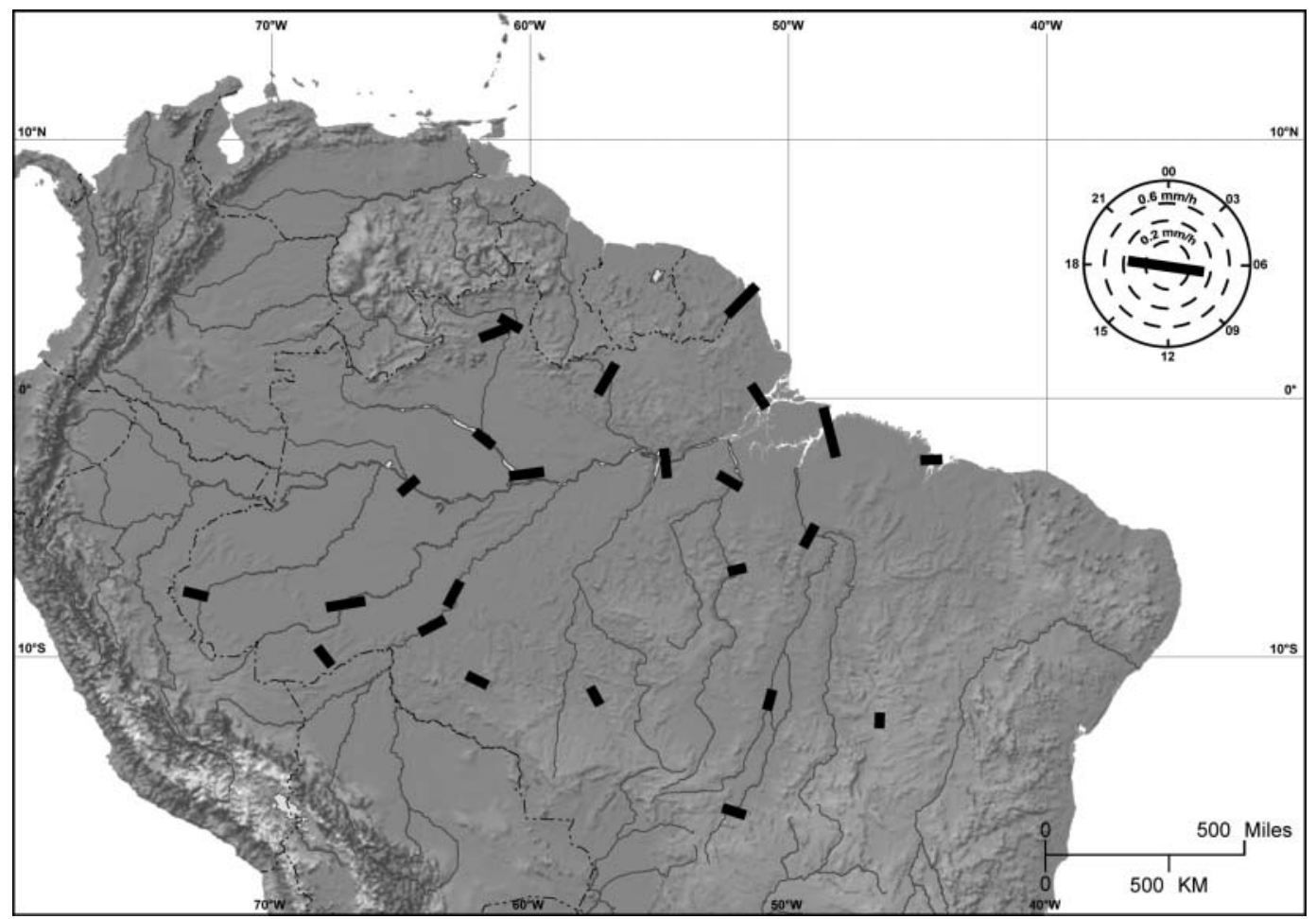

Fig. 6. Amplitude and phase of the second harmonic. The size of the symbol is the amplitude plus the mean rain rate for all hours. The symbol points to the hours (GMT) when the harmonic reaches its maximum 
Table 4. Phases of the first harmonic converted into hour (GMT). Annual, Summer and Winter: time when the precipitation reaches its maximum according to the phase of the first harmonic. Summer-Annual, Winter-Annual and Winter-Summer: difference between the hours of maximum rainfall assessed for each period

\begin{tabular}{|c|c|c|c|c|c|c|c|}
\hline \multicolumn{2}{|c|}{ Stn } & Annual & Summer & Winter & Summer-Annual & Winter-Annual & Winter-Summer \\
\hline \multicolumn{8}{|c|}{ Northern } \\
\hline 1 & Boa Vista & 04:09 & $03: 72$ & 05:91 & $-00: 37$ & 01:82 & $02: 19$ \\
\hline 2 & V. Apiaú & 03:63 & 02:08 & $04: 33$ & $-01: 55$ & $00: 70$ & $02: 25$ \\
\hline 3 & P. Norte & $00: 20$ & $23: 89$ & $00: 49$ & $-00: 11$ & $00: 29$ & $-00: 60$ \\
\hline 4 & Macapá & $06: 65$ & $08: 82$ & $03: 32$ & $02: 17$ & $-03: 33$ & $-05: 50$ \\
\hline 5 & Oiapoque & $11: 96$ & $11: 64$ & $12: 70$ & $-00: 32$ & 00:74 & 01:06 \\
\hline \multicolumn{8}{|c|}{ Eastern } \\
\hline 6 & Belém & $18: 16$ & $18: 14$ & $18: 29$ & $-00: 02$ & $00: 13$ & $00: 15$ \\
\hline 7 & Alcântara & $05: 77$ & 06:08 & $05: 77$ & 00:31 & 00:00 & $-00: 31$ \\
\hline 8 & Santarém & $05: 97$ & $05: 47$ & $05: 79$ & $-00: 50$ & $-00: 18$ & 00:32 \\
\hline 9 & Altamira & $15: 72$ & $15: 63$ & $16: 06$ & $-00: 09$ & $00: 34$ & $00: 43$ \\
\hline 10 & Marabá & $00: 74$ & $00: 59$ & $01: 28$ & $-00: 15$ & $00: 54$ & $00: 69$ \\
\hline 11 & S. F. Xingu & $18: 22$ & $18: 05$ & $18: 69$ & $-00: 17$ & $00: 47$ & $00: 64$ \\
\hline \multicolumn{8}{|c|}{ Central } \\
\hline 12 & Moura & $19: 16$ & $18: 40$ & $16: 44$ & $-00: 76$ & $-02: 72$ & $-01: 96$ \\
\hline 13 & Tefé & $13: 36$ & $14: 39$ & $07: 55$ & 01:03 & $-05: 81$ & $-06: 84$ \\
\hline 14 & Manaus & $14: 07$ & $13: 32$ & $14: 55$ & $-00: 75$ & $00: 48$ & $01: 23$ \\
\hline \multicolumn{8}{|c|}{ Central-Western } \\
\hline 15 & Humaitá & $00: 92$ & 03:04 & $22: 70$ & $02: 12$ & $-02: 22$ & $04: 34$ \\
\hline 16 & P. Velho & $23: 15$ & 00:06 & $22: 53$ & 00:91 & $-00: 62$ & $-01: 53$ \\
\hline 17 & S. G. Cachoeira & $14: 88$ & $15: 39$ & $20: 64$ & $00: 51$ & 05:76 & 05:25 \\
\hline 18 & C. Sul & $22: 27$ & $22: 08$ & $22: 98$ & $-00: 19$ & $00: 71$ & $00: 90$ \\
\hline 19 & Rio Branco & $17: 27$ & $16: 31$ & $18: 34$ & $-00: 96$ & 01:07 & 02:03 \\
\hline 20 & Jiparaná & $19: 72$ & $19: 44$ & $18: 81$ & $-00: 28$ & $-00: 91$ & $-00: 63$ \\
\hline \multicolumn{8}{|c|}{ Southern } \\
\hline 21 & P. Gaúchos & $00: 12$ & 01:06 & $23: 00$ & 00:94 & 01:12 & $-02: 06$ \\
\hline 22 & S. F. Araguaia & $09: 24$ & 09:04 & $20: 93$ & $-00: 20$ & $11: 69$ & 11:89 \\
\hline 23 & Taguatinga & $00: 54$ & $00: 54$ & $00: 90$ & 00:00 & $00: 36$ & $00: 36$ \\
\hline 24 & Aragarças & $15: 15$ & 13:87 & $00: 79$ & $-01: 28$ & 09:64 & $-10: 92$ \\
\hline
\end{tabular}

(June-November) diurnal rainfall pattern revealed no noteworthy differences to that of the annual diurnal cycle. Table 4 shows the first harmonic phases converted into hours extracted for 3 different periods. In the summer, peaks of precipitation tend to occur earlier in the day than in the winter. Variations in timing of the daily maxima of rainfall are attributed to the convective (stratiform) regime that prevails in summer (winter). The high values of the differences found for Tefé, São Félix do Xingu and Araguaia are attributable to the missing data, which have greater prevalence during the dry season. The results show that the diurnal cycle of rainfall is very similar for each period. This suggests that the low-level circulation over the study area is not strongly affected by seasonality.

\section{SUMMARY AND CONCLUSIONS}

This study has investigated rainfall characteristics over the Amazon based on $3 \mathrm{~h}$ time series compiled from 24 rain gauges over 3 yr (1 January 1998 to 31
December 2000). Results confirmed the high spatial and temporal variability of rainfall over the study area. The northern (southern) Amazon was the wettest (driest) part and the pronounced seasonality of the rain was clearly evident for almost all raingauge locations analysed, even along the eastern coast of the Amazon, where long periods of continuous precipitation occur. For all locations, a clear diurnal cycle of rainfall is evident; however, precipitation peaks occur at different times throughout the day. Harmonic analysis revealed that the amplitude of the first and second harmonics decreased from the Atlantic coast towards the central Amazon and increased again in the central and western Amazon. The first harmonic phase increased in a westerly direction from the Atlantic coast to the central Amazon. However, it would appear that this trend is not sustained beyond the central Amazon, as analysis results revealed an increase in the phase from the west towards the central Amazon. In contrast to previous studies, this finding raises the possibility that rainfall systems propagating from the east cannot 
reach the Andes Cordillera. Instead, westward propagation may occur due to the interaction of cold strong katabatic flows, originating from the eastern slopes of the Andes, with warm and moist air masses present over the Andes foothills. Such a hypothesis provides a strong justification for the investigation of Amazon Basin rainfall systems using mesoscale meteorological modelling that assimilates both satellite and observational data.

Acknowledgements. This work was undertaken with financial help from CAPES (Proc. BEX 1693/99-9). The authors would like to thank CPTEC-CMCD-INPE, ANEEL and CTA-IAE-ACA for kindly supplying the rain gauge data.

\section{LITERATURE CITED}

Costa MH, Foley JA (1999) Trends in the hydrologic cycle of the Amazon basin. J Geophys Res D 104(D12): 14189-14198

Cutrim EMC, Martin DW, Butzow DG, Silva IM, Yulaeva E (2000) Pilot analysis of hourly rainfall in Central and Eastern Amazonia. J Clim 13(7):1326-1334

Dai AG (2001) Global precipitation and thunderstorm frequencies. Part II: diurnal variations. J Clim 14(6): $1112-1128$

de Angelis CF, McGregor GR, Kidd C (2004) A 3 year climatology of rainfall characteristics over tropical and subtropical South America based on tropical rainfall measuring mission precipitation radar data. Int J Climatol 24:385-399

De Paiva EMCD, Clarke RT (1995) Time trends in rainfall records in Amazonia. Bull Am Meteorol Soc 76(11): 2203-2209

Figueroa SN, Nobre CA (1990) Precipitation distribution over Central and Western tropical South America. Climanalise 5(6):36-45

Garstang M, Massie HL, Halverson J, Greco S, Scala J (1994) Amazon coastal squall lines. Part I: structure and kinematics. Mon Weather Rev 122(4):608-622

Greco S, Swap R, Garstang M, Ulanski S and 5 others (1990) Rainfall and surface kinematic conditions over central Amazonia during ABLE 2B. J Geophys Res D 95(D10): 17001-17014

Hendon H, Woodberry K (1993) The diurnal cycle of tropical convection. J Geophys Res D 98(D9):16623-16637

Editorial responsibility: Clare Goodess,

Norwich, UK
Houze RA Jr, Geotis SG, Marks FD, West AK (1981) Winter monsoon convection in the vicinity of North Borneo. I. Structure and time variation of clouds and precipitation. Mon Weather Rev 109:1595-1614

Kayano MT, Ferreira NJ, Ramirez MCV (1997) Summer circulation patterns related to the upper tropospheric vortices over the tropical South Atlantic. Meteorol Atmos Phys 64: 203-213

Kodama YM (1992) Large-scale common features of sub-tropical precipitation zones (the Baiu frontal zone, the SPCZ and the SACZ). Part I. Characteristics of sub-tropical frontal zones. J Meteorol Soc Jpn 70:813-836

Kousky VE (1980) Diurnal rainfall variation in Northeast Brazil. Mon Weather Rev 108(4):488-498

Kummerow C, Barnes W, Kozu T, Shiue J, Simpson J (1998) The Tropical Rainfall Measuring Mission (TRMM) sensor package. J Atmos Ocean Tech 15(3):809-817

Lin X, Randall DA, Fowler LS (2000) Diurnal variability of the hydrologic cycle and radiative fluxes: comparisons between observations and a GCM. J Clim 13:4159-4179

Lloyd CR (1990) The temporal distribution of Amazonia rainfall and its implications for forest interception. Q J R Meteorol Soc 116(496):1487-1494

Marengo JA (1992) Interannual variability of surface climate in the Amazon basin. Int J Climatol 12:853-863

National Space Development Agency (NASDA) (2001) TRMM data users handbook. National Space Development Agency of Japan, Earth Observation Centre, NASDA, Tsukuba

Nobre P, Shukla J (1996) Variations of sea surface temperature, winds stress and rainfall over the Tropical Atlantic and South America. J Clim 9(4):2464-2479

Rao VB, Hada K (1990) Characteristics of rainfall over Brazil-annual variations and connections with the Southern Oscillation. Theor Appl Climatol 42(2):81-91

Simpson J, Adler RF, North GR (1988) A proposed Tropical Rainfall Measuring Mission (TRMM) satellite. Bull Am Meteorol Soc 63(3):278-295

Simpson J, Kummerow C, Tao WK, Adler RF (1996) On the Tropical Rainfall Measuring Mission (TRMM). Meteorol Atmos Phys 60:19-36

Souza EB, Kayano MT, Tota J, Pezzi L, Fisch G, Nobre C (2000) On the influence of the El Niño, La Niña and Atlantic dipole pattern on the Amazonian Rainfall during 1960-1998. Acta Amazon 30(2):305-318

Wilks DS (1995) Statistical methods in the atmospheric sciences. Academic Press, San Diego

Yang G, Slingo J (2001) The diurnal cycle in the tropics. Mon Weather Rev 129:784-801

Submitted: December 9, 2002; Accepted: March 9, 2004

Proofs received from author(s): April 21, 2004 